\title{
SCIENTIFIC AND CHARACTERISTIC DIMENSION OF 2013 CURRICULUM IMPLEMENTATION TO ISLAMIC RELIGIOUS EDUCATION (PAI) SUBJECT AT SMKN 2 BENGKULU
}

\author{
Zubaedi \\ State Institute for Islamic Studies (IAIN) Bengkulu, Indonesia \\ Jl. Raden Patah Pagar Dewa, Bengkulu \\ E-mail: zubaedi@iainbengkulu.ac.id
}

\begin{abstract}
The article examines 2013 curriculum (K-13) implementation of Islamic Religious Education (PAI) subject towards paradigm of scientific and characteristic. There were two issues to be discussed: First, how do the teachers plan the K-13 implementation? Second, how do the teachers implement the learning patterns of PAI subject according to K13? Qualitative approach was employed by understanding related-person performance in certain situation naturally, or without influenced by surrounding. In qualitative study analysis, inductive method was applied by overlooking initial hypothesis, while exploring the patterns, forms, and themes in examining data systematically. The present study found that the implementation of K-13 in PAl subject at State Vocational High School (SMKN) 2 Bengkulu run systematically and programmatically. The K-13 program was began with conducting training, designing program for annually, every semester, monthly, and daily, as well as for remedial program. The learning process of K-13 was implemented through introductory, core, and closing activities. The K-13 implementation indicated scientific-based learning, such as inquiry, discovery, problem solving, and video analysis. This implementation revealed that benefit to build religious character.
\end{abstract}

Keywords: scientific-based; syntax; competence; reasoning; collaborative learning.

\begin{abstract}
Abstrak: Artikel ini secara umum mengkaji implementasi kurikulum 2013 (K-13) dalam mata pelajaran Pendidikan Agama Islam (PAI) dengan paradigma saintifik dan karakter. Ada dua permasalahan yang akan dijawab dalam tulisan ini. Pertama, bagaimanakah langkah-langkah perencanaan yang dilakukan guru dalam mengimplementasikan Kurikulum 2013 yang berparadigma saintifik dan karakter? Kedua, bagaimanakah langkah-langkah guru dalam mengimplementasikan pola pembelajaran PAI sesuai paradigma kurikulum 2013 yang bercirikan saintifik dan karakter? Kajian ini menggunakan pendekatan kualitatitf. Sesuai dengan kerangka penelitian kualitatif, peneliti memahami peristiwa dalam kaitannya dengan orang dalam situasi tertentu secara wajar, langsung apa adanya, tanpa dipengaruhi unsur-unsur dari lingkungan. Analisis dalam peneletian kualitatif menggunakan cara induktif dengan mengesampingkan hipotesis awal, namun mencari pola, bentuk dan tematema dalam mengungkapkan data secara sistematis. Tulisan ini mengungkapkan temuan bahwa implementasi kurikulum 2013 dalam mata pelajaran PAI di Sekolah Menengah Kejuruan Negeri (SMKN) 2 Bengkulu berjalan secara sistematis dan terprogram. Diawali dengan pelatihan kurikulum 2013 di kalangan guru PAI, penyusunan program tahunan, program semester, program mingguan dan harian, dan program remedial. Implementasi K-13 dalam pembelajaran melalui kegiatan awal, kegiatan inti, dan kegiatan akhir dalam pembelajaran. Pembelajarannya terbukti menggunakan rambu-rambu saintifik, yaitu: inkuiri, diskoveri, pemecahan masalah, dan analisis video. Implementasinya terbukti bermanfaat secara positif penanaman karakter religius.
\end{abstract}

Kata kunci: saintifik; sintaks; kompetensi; menalar; pembelajaran kolaboratif.

\section{Introduction}

Curriculum change is inevitable. The government, in this case is Ministry of Education and Culture (Mendikbud), is planning to change the curriculum of 2013/2014 forward. As stated by the minister that 2006 school-level autonomy curriculum (KTSP) is changed into
2013 curriculum (K-13), officially launched in July 2013 which gradually implemented throughout the schools.'

${ }^{1}$ Titiek Rohanah Hidayati, “Implementasi Pengembangan Kurikulum 2013 Dalam Pembelajaran Pendidikan Agama Islam dan Budi Pekerti Di SMA Negeri 4 Jember", An article in Jurnal Fenomenal (Jember: IAIN Jember, vol. 14, no. 1 (April 2015), p.2 
K1-3 emphasizes character education, specifically for primary level which fundamental for the next level of grades. Through K-13 development of character and competence based, the minister hopes that the nation becomes the dignified nation with added value people, could have selling value that can be offered to other people and other nations of the world. This curriculum is also expected to be able to solve the nation's problems, especially in education. It is accomplished by preparing the students through planning, implementing, and evaluating the education system effectively and efficiently. Therefore, it is a positive beginning when the minister attempts to restore character education in all levels of grades, including the 2013 curriculum development.

In the other side, reaction occurs in other regions. The pros and cons followed as the curriculum has implemented in this school. However, once the policy officially launched, the whole parties should enforce $\mathrm{K}-13$ as expected. The K-13 implementation is scheduled gradually and selectively, primarily for A-accredited or former international-standard schools. ${ }^{2}$ The example of the school which commits to provide $\mathrm{K}-13$ implementation is SMKN 2 Bengkulu. Without doubt, this school immediately prepares three stages: socialization, preparation, and implementation.

$\mathrm{K}-13$ implementation in this school includes Islamic religious education (PAI). Enforcing $\mathrm{K}-13$ in PAl is interesting to be investigated further, since both $\mathrm{K}-13$ and PAI are highlight character building to students. Accordingly, PAI director claims that $\mathrm{K}-13$ belongs to Islamic education studies teacher. It is represented by first competences standard (SKL) requirement that reflects the attitude of those who have believed and noble morals. It is also stated that first core

${ }^{2}$ K-13 is implemented gradually from 2013/2014 school year and limited, specifically for school which ready to employ K-13. In first stage, 2013/2014 school year, K-13 is limited to Grade I and IV at elementary/Islamic elementary school (SD/ $\mathrm{MI}$ ), grade VII senior/Islamic high school (SMP/MTs), and Grade $X$ secondary school level/vocational/Islamic secondary/Islamic vocational school (SMA/SMK/ MA/ MAK). Later, in 2015/2016, it is expected that $\mathrm{K} 13$ had been implemented in all levels of grades, from elementary to secondary high scho competence of all subjects always begin with the sentence appreciates and lives the teachings of the followed religion? ${ }^{3}$.

A subject which has mandate and mission in attitude building is Islamic religious education (PAI). PAI subject understanding at school can be identified towards two points, PAl as activity and the other as phenomenon. Subject as activity means that conscious effort to help individual or grouped who develop the way of life. It is the Islamic-based way how people will live their lives and beneficial to lives, life attitudes, and life skills, both manually (practical direction) and mentally, as well as socially. However, as phenomenon reflects the events which incorporate two or more creations of surrounding impact. This creation is embodied through Islamic-based life attitude and skills of one or some who involved 4 .

Currently, attempts to improve PAI subject quality is necessary to provide fresh atmosphere in education development. It also expected to bring contribution in defining the core of education as stated in National Education System (Sisdiknas) Law No.20/2003: to develop capabilities and build the nation's character and civilization with dignity in order to educate the life of the nation; to develop the potential of students to become human beings who have believed and fear God Almighty, have noble, healthy, knowledgeable, capable, creative, independent, and be a democratic and responsible citizen.

Theoretically, PAI subject is an attempt to prepare the students knowing the Islamic education, doing the teaching, and being a Moslem in everyday life. Teaching the subject relies on followed objectives: to improve the comprehension, implementation, and practice to everyday life. The main purpose of the subject is diversity to become the real Moslem. This diverse environment is overlooked while teaching PAl subject.

\footnotetext{
${ }^{3}$ Mumu Jajuli, “Kurikulum 2013 Milik Guru PAl”, Pendis. kemenag.go.id, http://www.pendis.kemenag.go.id/pai/index. php?a=detilberita\&id=5640, Accessed, March, 32017

${ }_{4}$ Muhaimin, Pengembangan Kurikulum Agama Islam, (Jakarta: RajaGrafindo Persada, 2010), IVth print, IV, p. 15. Also See. Qomaruzzaman, Bambang. "Religious Inclusivity in Islamic Education Course Book of the 2013 Curriculum." MADANIA: JURNAL KAJIAN KEISLAMAN, vol.22, no.2 (2018), pp. 195-210.
} 
Religion education is defined as an attempt actualizing the qualities of perfection that Allah SWT has bestowed upon humans, which are carried out without any strings attached except to merely worship Allah. Other experts also agree that religious education is as a process of delivering information in building faithful and pious people, so that people are aware of their position, duties and functions in the world by always maintaining their relationship with God, himself, society and the natural surroundings as well as responsibility to the One and Only God (including himself and his environment).

Since the importance of Islamic education comprehension, it is essential to build the student's awareness profoundly to materials. Therefore, PAl should be the priority among other subjects. To achieve this goal, teachers require to develop appropriately in order to design the objective, materials, methods, media, and evaluations harmoniously, so that understandable and inspiring for students.

The development of content is basically whole set of activities and experiences which develop and arrange to achieve the education goals. Not only does consist of set of knowledge of information, but also selected knowledge integration which are needed for the knowledge, as well as student with environment followed'.

There are two considerations when designing the content. First, the content is defined as material for learning and teaching. The material encompasses factual information, knowledge, skill, concepts, attitude, and value. Second, in learning process, the curriculum elements (discussion and method) interact constantly. The discussion address significance to students concerning case and approach, namely methods and learning activities. Content and method are intertwined; however, both are separated into curriculum elements, each of which can be assessed with different criteria. Both content and methods must be significant so that the results of effective learning can be achieved well.

Alfiatu Solikah, "Pengembangan Tujuan dan Isi Kurikulum Pendidikan Agama Islam", an article in alfykdr. blogspot.com, published on 16 June 2013, from http://alfykdr. blogspot.com/ 2013/06/tugas-kuliah.html.
Related to aforementioned consideration, the problem statement of present study is how the teachers develop PAI scientific and characteristicbased curriculum as a response to $\mathrm{K}-13$ in SMKN 2 Bengkulu. Operationally, the present study focuses on finding out two problems followed: how do the teachers plan $\mathrm{K}-13$ implementation with scientific and characteristic paradigm? Second, how do teachers' syntax (process) in implementing PAI learning pattern with scientific and characteristic based curriculum?

\section{Curriculum Implementation Significance}

The curriculum has a central position in educational activity. This position shows that the main element in each education unit and educational activity represents process of academic interaction among students, educators, resources, and the environment. It also indicates that academic interaction is the soul of education. Educational or teaching activities cannot be completed without interaction and curriculum, since the activities are the design of this interaction.

The curriculum implementation is part of the curriculum development process. Without implementation, curriculum development will not achieve its objectives. The implementation of the curriculum is an attempt to realize the ideas, concepts, and values contained in the written curriculum into reality. Implementation of the curriculum can also be interpreted as actualizing the written curriculum in terms of learning. ${ }^{6}$

Hadi Kuncoro in Majid according to Johan P. Miler \& Waine Sailer argue that 'Implementation, a major component in the curriculum process, has been neglected by curriculum theorists. In some cases, implementation has been identified with instruction,... Implementation is defined as an event'. According to Fullan in Miller in Majid, implementation is a process of practicing or applying an idea, program or set of new activities for people who desire to change. ${ }^{7}$ It

\footnotetext{
${ }^{6}$ Hasan, Evaluasi Kurikulum (Bandung: Remaja Rosdakarya. 2009), p. 11.

7 Hadi Kuncoro, “Peran Kepala Sekolah Dalam Implementasi Kurikulum 2013 di Sekolah Menengah Pertama Negeri 1 Gisting Kabupaten Tanggamus Tahun Pelajaran 2014/2015", Master Thesis
} 
also consistent with Murray Print's view that implementation is a short-term phenomenon that attempts to integrate new curriculum into existing practice. Miller \& Seller suggest that 'In some cases, implementation has been identified with instruction...'. Further, implementation is a process of achieving concepts, idea, programs, or curriculum design into learning activities or brand-new activities. Therefore, transformation occur in a group of people who are expected to change. Another explanation highlights that implementation related to curriculum is as argued by Saylor and Alexander. They agree that learning process as common implementation: the curriculum and teaching including response to interaction delivered by teachers and students at school. As independent field of study, curriculum implementation has related specific objectives and procedures. It also defines as written curriculum actualization in sets of learning opportunities.

Further, implementation is a process of practice, idea, concepts, policy, and innovation in practical performance, so that create impacts, such as knowledge, skill, value, and attitude shift. In short, curriculum implementation defines as written curriculum which embody written curriculum in learning. ${ }^{8}$

Once the designs have been created, the curriculum is implemented. The teachers specify the curriculum and select the teaching method according to current situation, such as student needs and interest as well as intellectual, emotional, and physical development. ${ }^{9}$

Curriculum implementation process involves activities related to student goals in achieving knowledge and experience, since student is a central and vital actor in curriculum implementation. Nevertheless, there are many factors influenced the implementation process, such as resource and facility materials, teachers, school environment, culture and ideology,

(Lampung: Postgraduate Program of Education Management, Faculty of Teaching and Education Sciences, Universitas Lampung, 2015), pp. 18-19.

8 Kunandar. Guru Profesional Implementasi Kurikulum Tingkat Satuan Pendidikan (KTSP) dan Sukses Dalam Sertifikasi Guru. (Jakarta: Raja Grafindo Persada, 2007), p. 211

9 Oemar Hamalik, Dasar-dasar Pengembangan Kurikulum, (Bandung: PT. Remaja Rosdakarya, 2007), p. 238 instructional supervision, and assessment. Implementation occurs when the student acquires expected experience, knowledge, idea, and attitude which effectively brings impact to society. Therefore, curriculum implementation refers to how the programs are planned or designed by the teacher into the syllabus, work schemes and lessons that will be delivered to students later. Implementation as an important part of curriculum development, brings anticipated changes and changes that occur in several ways. ${ }^{10}$

Implementing new curriculum by Mendikbud aims to improve education quality. It is compulsory because curriculum adjustment need to be established gradually, according to several outcomes: 1) vision and mission of educational institution; 2) community demands (including future job market); 3) science and technology development. ${ }^{11}$ Successful curriculum implementation depends to teachers and educational institution arrange and implement their learning and assessment process. It is because educational system quality is strongly correlated with teacher quality. Teachers have strategic roles in determining education quality. Nevertheless, lack of qualified resources commonly occurs which high-quality teachers are required. To sum up, teacher existence is front-line education actor to escalate qualified education and education outcomes.

Curriculum implementation conducts in two ways. First, slow change and rapid change. The slow change indicates as we do minor adjustment to course schedule, add some books to library, or update the unit plan, and others. While rapid change occurs as a result of new knowledge or social trends influencing the curriculum, such as computers education being introduced in the curriculum, and others. ${ }^{12}$

${ }^{10}$ Solomon Bediako, "Implementation, Some Definitions and Influence Of Implementation", An article in researchgate. net/publication, , accessed on June 6, 2020.

${ }^{11}$ Amat Jaedun, V. Lilik Hariyanto, Nuryadin, E.R, "An evaluation of the implementation of Curriculum 2013 at the building construction department of vocational high schoos in Yogyakarta", Journal of Education, vol. 7, no. 1 ( November 2014), p.15

${ }^{12}$ Solomon Bediako, "Implementation, Some Definitions..., accessed Mei, 16, 2020. 
Curriculum implementation terms have been suggested in different ways by some scholars. For instance Solomon Bediako in Garba argue that curriculum implementation is a process to place curriculum as activities to achieve its goals. Solomon Bediako Okebukola (2004) argues that it describe as an interpretation of curriculum objectives from written to practice. Simply, Ivowy agree that it is transformation of "theory to practice" or "proposals into action". Mkpa and Izuagba in Obilo and Saugoleye state that curriculum implementation is the actual involvement of students with planned learning opportunities; This plan includes teaching material that will be used for its implementation at an appropriate stage. Moreover, Yobe in Anneke depicts curriculum implementation as the task of translating curriculum concepts into operational curricula with the combined efforts of teachers and the community. ${ }^{13}$

Solomon Bediako correspond to Fullan in Owusi suggests that curriculum implementation is a process to bring the document and learning program into practice. Leithwood (1982), as other curriculum experts, asserts that implementation is a process to diminish reduces the difference between existing practices and practices proposed by innovators or change agents. Implementation is the act of applying the specified curriculum into practice in schools. Curriculum implementation is a final goal of curriculum development process. It because once the process done, the students have opportunity to gain learning experience from the curriculum and benefit from it. Align with above mentioned, Solomon Bediako referring Agangu's in Aneke states that the curriculum is a mechanism in which education system transmit the students with the knowledge, skills and attitudes that have been determined by the community. ${ }^{14}$

Therefore, curriculum implementation regards to how program created is incorporated to syllabus, work schemes, and courses delivered to students. Implementation as prominent part in

\footnotetext{
${ }^{13}$ Solomon Bediako, "Implementation, Some Definitions..., accessed Mei, 16, 2020

${ }^{14}$ Solomon Bediako, "Implementation, Some Definitions..., accessed Mei, 16, 2020
}

curriculum development which leads to expected transformation. The relationship between curriculum implementation and development as presented below:

\section{Method}

Qualitative approach was employed in this present study. Therefore, the researcher conducts field study by gathering objects in limited time. SMKN 2 Bengkulu was the location to collect the data. According to qualitative study, the researcher investigates related-person events in certain situation naturally, or without influenced by surrounding. ${ }^{15}$ Inductive approach was applied to analyze the data by neglecting initial hypothesis, but exploring patterns, forms, and themes in examining the data systematically. While qualitative data employed, the quantitative data was used to measure and reveal value, mental attitude, habits, belief, and culture of an individual or group of people in certain environment.

The aforementioned data was collected by field observation, depth-interview, and literature review. Field observation encourage the researcher intervenes the environment so that minimize the rigidness which tend to break friendly environment made. Interview was conducted to selected informants among PAI teachers, headmaster, student's parents, and student's representative. Casual interview was the method used for interviewing. Informants were selected by considering the relevance of authority and capabilities developed. It is relevant to Singarimbun's opinion that the informant must be someone who has the knowledge and attitude that is relevant to the purpose of the study. ${ }^{16}$ In understanding and interpreting existing data, researchers will use a sociological approach to religion that sees social objects, knowledge, practices, and institutions due to social interaction with religion, so that it becomes social. ${ }^{17}$

${ }^{15}$ Lexy Moeloeng, Metodologi Penelitian Kualitatif(Bandung: Rosdakarya, 1995), p. 23.

${ }^{16}$ Masri Singarimbun dan Sofian Effendi, Metode Penelitian (Jakarta: LP3ES, 1997), p. 145.

17 Michael S. Northcott, Sociological Approach, in Apprroaches to the Study Of Religion, Eds: Peter Connolly (London, Wellington House, 1999), p. 193. 


\section{Result \\ Process of Curriculum Implementation}

SMKN 2 Bengkulu is quite popular in Bengkulu due to well-managed PAI learning tradition and patterns. Consequently, public interest to be a student in SMKN 2 Bengkulu is quite high. ${ }^{18}$ Concerning to the daily behavior of students, the school never been involved in student's criminal or immoral cases. Currently, PAl subject taught is based on 2006 school-level autonomy curriculum (KTSP) provisions and it had been running well as expected. However, 2006 KTSP curriculum was no longer implemented since the government launched new curriculum, namely 2013 Curriculum (K-13) on 14 July 2013. This change absolutely surprised the teachers who already settled with 2006 KTSP.

Becoming a school where $\mathrm{K}-13$ has been implemented, all teachers including PAI teachers have involved in preparation series to implement the curriculum, such as socialization and curriculum document review, syllabus analysis, teacher's and student's book review, classroom teaching plans (RPP) designs, learning activities, and evaluation. These preparations are adjusted to education paradigm requirement in $\mathrm{K}-13$ which emphasizes character building and scientific learning.

In terms of implementation, the minister assumes that it will be more complicated than previously. The teacher is the spearhead of the $\mathrm{K}-13$ implementation because students need to strengthen and assist in developing the attitudes and character of students that are emphasized in the $\mathrm{K}-13$.

One of the changes in the 2013 Curriculum is the subjects merging. In addition, the government also plans to add class hours so that learning emphasizes the students' character. New approaches and assessments provided are namely scientific approach and authentic assessment, which requires the teacher's preparation to apply them consistently in learning. As the subject

${ }^{18}$ Total classes of Grade X in SMKN 2 Bengkulu is 19 classes, with total of 504 students. The program of strengthening the PAl subjects is carried out through scheduling every Saturday conducted by bimtak, every month a mabit (recitation) is conducted, the ubudiyyah activities, reflections, and teacher recitation. Interview with PAI Teachers at SMKN 2 Bengkulu, Mawardi, March 26, 2014 relies on religious character, PAI is an effort by guidance and care for students. It is expected that after completing their education, they could understand and practice the Islamic value and make it a way of life.

The abovementioned explanation shows that educational process requires $\mathrm{PAI}$, a subject that support the development of students' values and morals. The urgency of PAI role in current education process lead PAI to get more attention in developing student morale.

The great success of conducting education in SMK is achieved even if the learning process could bring impact to student's attitude pattern as designed in education outcomes. It can be also effectively established if the teachers prepare and plan the classroom activity well for three missions: 1) Accomplish the needs of the local community and global community. 2) Prepare students to face the development of the global world. 3) Continue to a higher level and/or develop independent life skills.

As comparison, take an example of the previous grade in elementary school (SD) and junior high school (SMP). In SD, attitude domain has more portion than skills, whereas knowledge is the lowest. In SMP, dominated domain is attitude, with more skills and knowledge rather than those in SD. However, the elements of attitude, skills, and knowledge have fair portion in senior high school (SMA) and vocational high school (SMK). This is completely different while in higher education, skills and knowledge are dominant, and overlook the attitude elements. Specifically, the change of curriculum implementation of $\mathrm{K}-13$ in PAl subject should not be thematically implemented since overlapping among other religion subject teachers ${ }^{19}$.

The adjustment in PAI occurs to course duration and naming, from 2 hours to 3 hours a week, and it has different names into Islamic Education and Manners Studies. In PAI learning approach, K-13 introduces novel approach, namely scientific approach or commonly known as scientific skills process approach.

19 Interview with PAI Teachers at SMKN 2 Bengkulu, Mawardi, March 26, 2014 
Tohirin, vice headmaster, argues that SMKN 2 had been passed the first term of $\mathrm{K}-13$ implementation students. Scientific-based curriculum is initiated with training series, then to be implemented after the teachers complete training series. He also stated that learning indicator of PAI is based on K-13 learning standard encompass $5 \mathrm{M}$ in Bahasa Indonesia: observation, enquire, practice, correlate, and communicate. In order to prepare the implementation, some trainings had conducted by sending the PAI teachers to join the K-13 preparation training ${ }^{20}$, "teachers are already involved in K-13 learning. They share what they have got during training to other teachers. Moreover, they also learn K13 through The PAI Teachers Association (MGMP)", he said.

The objective of implementing K-13 personal experience-based learning through observationbased learning is to increase student's creativity. In addition, the student will get used to work in networks through collaborative learning. Creativity obtained through a supportive learning process, which emphasizes student activities that are observation, inquiry, association, experiment, and networking. ${ }^{21}$

First, observation-based learning is including reading, listening, paying attention, noticing (with or without tools). The competences developed are practice seriousness, accuracy, and look for information. Observation method prioritizes meaningful learning process. In broader context, tools or instruments used in conducting observation are checklists, rating scales, anecdotal records, periodic notes, and mechanical devices.

Second, inquiry-based learning accomplished by asking questions about unclear information to get additional information about what is observed (starting from factual questions to hypothetical questions). The questioning-based activity aims to motivate students to improve and develop their attitude, skills, and knowledge. Once the teacher asks, students would get guidance and direction at the same time.

\footnotetext{
${ }^{20}$ Interview with informant, Tohirin, on August 11, 2017

21 Muhammad Nuh, Paparan Menteri Pendidikan dan Kebudayaan Pengembangan Kurikulum 2013. (Semarang: Kemendikbud, June 2013), p. 49.
}

Third, exploration-based activity is a first beginning to gather information/experiments include: conducting experiments, reading sources other than textbooks, encouraging objects/ event/activities; and interviewing informants. Competencies developed in exploration-based learning are developing a conscientious, honest, polite attitude, respecting the opinions of others, communication skills, increasing the ability to gather information through various ways, developing learning for lifelong learning skills.

Fourth, case-based association activity is a form of learning process in which teachers and students are the active actors. It emphasizes active learning that students to be more active than teachers. Associating is a logical and systematic thinking process over empirical facts to be observed, so that students obtain the conclusions in form of knowledge. This approach refers to scientific reasoning, although non-scientific is not always useless. The term of associating is different from reasoning, although both words have the same meaning. Hence, case-based association in terms of 2013 curriculum refers to associative learning theory which categorizing ideas and associate events to be processed into piece of memories. During transferring specific events to the brain, memory stored is correlated with another event. Experiences stored in the brain associate and interact with another previous experience. Therefore, this process is known as association. In psychology perspective, association refers to connection between conceptual entities or mental as a similar result between thinking, and space and time similarity. ${ }^{22}$

Fifth, communication learning activities delivers the observation, conclusion is according to verbal and written analysis. Competence developed in communication stages are developing honesty, conscientious attitude, tolerance, ability to think systematically, express opinions briefly and clearly, as well as develop good and correct language skills.

${ }^{22}$ Syawal Gultom, Modul Pelatihan Kurikulum 2013 (Jakarta: Human Resources Development Agency for Education and Culture and Education Quality Assurance, Ministry of Education and Culture 2014), p. 41. 
$\mathrm{K}-13$ i-mplementation within PAI subject teachers in SMKN 2 Bengkulu is guided by Ministry of Education and Culture Regulation (Permendikbud) Attachment IV 81. A 2013, which $\mathrm{K}-13$ refers to 8 educational standards that have changed only occurs in 4 standards, namely content standards, process standards, assessment standards and graduate competency standards. Regulation change the previous curriculum implementation, as a minimum reference for the education administration applied to all primary and secondary educational institutions in all jurisdictions in Indonesia. KTSP (2006 curriculum) National Education Standards (SNP) based on Presidential Regulation No. 19 of 2005, while the $\mathrm{K}-13$ is by Permendikbud regulation.

PAI with $\mathrm{K}-13$ design, philosophically is designed to generate students with Islamic characteristic, faithful to Allah, and able to perform Islamic law in kaffah (whole) and istiqomah (steadfastness), behave with noble morals in a harmonious life in order to achieve ultimate prosperity and happiness in the world and the hereafter. Hierarchically, the standard of $\mathrm{PAI}$ with $\mathrm{K}-13$ is described into Core Competencies (KI) and Basic Competencies (KD) as well as Learning Objectives (TP). ${ }^{23}$. Core competencies of K13 consist of four main competencies as follows:

1) Core One / KI-1 (Spiritual) Competence: respecting and living the teachings of the religion they hold.

2) Core Competencies Two / KI-2 (Social): respect and appreciate honest behavior, discipline, responsibility, care (tolerance, mutual cooperation), polite, confident in interacting effectively with the social and natural environment within the reach of relationships and their existence.

3) Third Core Competency / Kl-3 (Knowledge): understanding knowledge (factual, conceptual, and procedural) based on curiosity about science, technology, art, culture related to phenomena and events seen in the eye.

${ }^{23}$ Djemakin Mukadi, "Kurikulum 2013: Mata Pelajaran PAI" dalam Gurupaisma1 purbalingga. blogspot.com, published on 10 June 2013, http:// guru paisma 1pur balingga.blogspot. com/ 2013/06/kurikulum-2013-mapel-pendidikan-agama.html, accessed on March 2, 2014
4) Four Core Competencies / Kl-4 (Skills): try, process, and serve in the realm of concrete (using, decomposing, stringing, modifying, and making) and abstract domains (writing, reading, calculating, drawing and composing) in accordance with those studied in schools and other sources that are the same in point of view / theory.

Abovementioned competencies become the main competencies and must exist in all subjects in all primary and secondary education units including Islamic PAI subject. Then, the subject is detailed into Basic Competencies (KD) on each subject including PAI. The basic competencies in PAI is designed for all level of grades, from elementary of SD/MI to secondary levels of SMP/ MTs (junior high school), SMA/MA (senior high school), and SMK/MAK (vocational high school).

PAl with $K_{13}$ implementation in SMKN 2 Bengkulu conducts in three stages. First, preparation including arrangement of annual, semester, weekly, daily, and remedial program. Second, implementation through introductory, core, and closing activities. Third, curriculum evaluation through assessment on attitude, knowledge, and skills competence.

\section{Implementation of Scientific Learning in PAI}

Competence implemented in SMKN 2 Bengkulu employs lecture method, media, and discussion with a scientific approach (scientific approach). PAI learning uses many scientific methods, they are inquiry, recovery, and problem solving.

SMKN 2 Bengkulu has been implementing K-13 since 2015. PAl teachers attended the $\mathrm{K}-13$ training to develop the curriculum more. According to Eka Dianti, the principles of PAI scientificbased curriculum development implemented while designing, teaching, and evaluating the PAI learning result. For instance, PAI teacher deliver the lecture with muamalah-commercemention topic, scientific approach performed by inviting children to observe the practice of trading activities in daily life. ${ }^{24}$

${ }^{24}$ Interview with informant, Eka Dianti, on August 11, 2017. 
Scientific learning has been applied in hajj and umrah pilgrimage topic. In teaching halal (permitted) and haram (prohibited) foods topic, PAl teachers can develop children's scientific abilities by inviting children to examine the causes of prohibited drugs. Children are taught to discuss the causes of illicit drugs with a cross-disciplinary approach both medically, psychologically, and sociologically.

Moreover, PAl teacher deliver akhlaq (morality and manners in Islamic philosophy) topic course, such as positive prejudice or selfcontrol, by encouraging students to reason what psychological and sociological effects are when a person always think a positive prejudice (husnuzzhan) and has a self-control. Students are also stimulated to demonstrate the benefits of positive prejudice and self-control and contrast case for instance, a person who does not have self-control and keep thinking negative (suuddzhan). Reflecting learning on such topics, PAl teachers employ card short technique to illustrate students about matching pairs between self-control trait and the examples. The students are asked to match the cards and write the pairs on the classroom board.

Concerning to figh (Islamic jurisprudence) topic subject, for example in treating corpse, the PAl teachers use computer and PAI laboratory then body puppet model as an illustration of corpse. Likewise, teachers employ sets of hajj and umrah pilgrimage props in the classroom to illustrate practical learning in PAI laboratory. While demonstrating shalat (Muslim prayer), the teachers utilize Google to present unclear topics that has been delivered conventionally. PAI teachers use LKS (student worksheets) and commercial textbooks by Yudhistira and Erlangga pusblisher. PAI teachers tends to complete student evaluation toward multiple choice test, while essay written test rarely been employed.

Conveying halal and haram foods, the teacher operates InFocus projector and short videos as well as images that present the harm of consuming drugs. For example, glue sniffing, the videos explain glue harmfulness for nerves. Moreover, topic on development of Islam (PAI on history of Islam) is delivered through video games that facilitate students to observe the storyline while watching and analysing the video. ${ }^{25}$

\section{Character Building in PAI Learning}

It has been acknowledged by some teachers that efforts to cultivate the values of religiosity are challenging. This requires teamwork between the teacher, as the teaching team and another related party. According to information obtained, it revealed that religiosity values have been introduced to students towards religious-based activity. It is expected that such activities resulting to religious habitual in daily life with morality and ethical values. Morality and ethical values can be stimulated by religious activity as follows:

1) Pray and be grateful. Praying is a direct expression of gratitude to God. Expressions of gratitude can also be manifested in one's relationships or relationships with others, namely by building brotherhood without being limited by ethnicity, race, and social class. Greeting religious holiday to nonMuslim is showing respect that can be developed in school-aged children conscious. Gratitude to nature can be expressed by watering plants, throwing trash in its place, and treating animals well.

2) Conduct activities in mushalla (praying room). In school mushalla, many activities can be carried out to initiate religious attitude as a habit, such as do Zuhr (midday) and Friday prayer in jama'ah (congregation) regularly as well as recite and learn Quran. The moral value within activities can be a provision for students in schools to behave with morality and ethical values.

3) Celebrate religious holidays in accordance with their respective religion. For those who are Muslim, the moments of Eid al-Adha, Isra' Mi'raj, and Eid al-Fitr can be used as a means of increasing faith and piety ${ }^{26}$

${ }^{25}$ Interview with informant, Eka Dianti, on August 11, 2017.

26 Interview with informant, Mawardi, 23 September 2017. See. Heny Sulistiyowati, "Analisis Pelaksanaan Kegiatan Pengembangan Diri Keagamaan dan Life Skill Untuk Meningkatkan Kemandirian Peserta Didik Di SD Muhammadiyah Birrul Walidain Kudus Tahun Pelajaran 2015/2016", Undergraduate Theses (Kudus, STAIN, 2016), p. 22. 
In terms of character building to get closer to God, the students are provided to understand and appreciate Asmaul Husna (99 names of Allah) such as al-karîm, al-mu'min, al-wakîl, al-matîn, al-jâmi', al-'adl, and al-akhîr. It is expected that students could implement akhlaqul karîmah (good manners), for instance: avoid chaos at school and in the community, have willingness to forgive friends who hurt, provide help who needs, invite and encourage other students to pray and do good deeds, complain less when disaster strikes, hit by fear when remembering death, try hard accomplishing the task, provide solutions to friends who are in trouble, try to improve good deeds so that good charity continues, forgive easily to friends/other who made mistakes. ${ }^{27}$

\section{Discussion}

SMKN 2 Bengkulu teachers have attempted to implement scientific learning principals for classroom activities with firm mission to strengthen the values of character. This implementation employed in learning design process, such as syllabus, RPP, methods, and learning assessment instruments. Implementation also performed during five stages of learning process: observation, inquiry, practicing, association, and presentation. Curriculum implementation conducted by PAI teachers subject of SMKN 2 Bengkulu with following patterns 1) substitution, 2) alteration, 3) variation, 4) restructuration, and 5) novel orientation. It is a substitution-based development in the form of replacing a textbook into better quality textbooks, however the replacement has not fully carried out. Hence, this substitution has been continued to be endeavoured by compiling subject materials obtained from the Religious Affairs Ministry (Kemenag), Education and Culture Ministry (Mendiknas), and LKS.

Conveying topic on generosity, one way to develop the course topic is by direct practice. As the students finish their jama'ah prayer, charity box was distributed to all the students. The students also compulsory to join extracurricular activities, like RISMA (young activist of the mosque) or

${ }_{27}$ See. Nelty Khairiyah and Endi Suhendi Zen, Pendidkan Agam Islam dan Budi Pekerti SMA/MA, SMK/MAK, (Jakarta, Education and Culture Ministry, 2017), p. 16.
ROHIS (Islamic spirituality lectures) every Friday afternoon, from 14.00 to Asr (afternoon prayer) time and closed with jama'ah prayer. This effort is a step for students' self-development. Every week, students are also guided to study the Quran. ${ }^{28}$

Such activities are another small part of changes due to only book substitution. Alteration is a kind of curriculum change by adjusting study hours for PAI subject. According to informant, alteration is a method in curriculum development by conducting bimtek (technical guidance) of imtaq (faith and piety) twice a month, in second and fourth week, at 07.30 to 08.15 in respective workshops.

For instance, material during Muharram month is delivered in the form of rewardingbased quiz. Those who can answer correctly, the students will get money and taqiyah (cap). The amount of which from IDR 5000 to 50.000 is depending to question difficulties. The example of difficult question: The students are asking the meaning of Surah An-Nûr [24]: 52, or Al-Baqarah [2]:153, which the amount of this reward is IDR 50.000 .

Curriculum change in varied activities mentioned aims to accept and apply a method that works in other schools to run in their own schools, by eliminating the conventional method. Hence, these are more difficult than usual, due to require teachers' innovation in learning and mastery the new method. For instance, delivering topics on treating corpse by video based on Indonesia's two largest Islamic organizations, Muhammadiyah and Nahdlatul Ulama (NU) way. PAI teachers facilitate observation and listeningbased material, then conclude the discussion with proper understanding.

PAI scientific learning in SMKN 2 Bengkulu was currently limited, however figh dominated the whole dimension of PAI materials. Scientific learning should have been more comprehensive, specifically topic on aqidah akhlak, history of Islam (SKI), Al-Quran, Hadith (news or story), through innovative activities such as varied video, poster, game, and any other media.

\footnotetext{
${ }^{28}$ Interview with informant, on September 24, 2017
} 
Furthermore, PAI learning in SMKN 2 Bengkulu found that it was dominated by character building of religious values, tolerance, discipline, and curiosity. From the research findings, this could be further implemented character building values broadly and implicitly, including honesty, hard-working, creativity, independence, democracy, national spirit, love for the motherland, achievement appreciation, friendship, communication, literacy oriented, environmental and social awareness, and responsibility.

\section{Conclusion}

According to abovementioned description, there are two conclusions: First, curriculum development of Islamic Religious Education (PAI) subject in SMKN 2 Bengkulu is conducted towards stages of $\mathrm{K}-13$ implementation preparation planning. The preparation is held independently at school and teachers are sent to attend the $\mathrm{K}-13$ training outside the school. Second, PAI subject teachers conduct K-13-based classroom teaching plan (RPP), remedial and enrichment program. In this following process, PAl teachers are involved in designing annual, semester, weekly, daily program to implement K-13-based subject. The teachers implement RPP through classroom activities: introductory, core, and closing activities. In learning activities, it revealed that PAI subject teachers employed scientific-based methods, they are inquiry, discovery, problem-solving, and video analysis. Moreover, in terms of character building, it was performed through programmed-based learning activities to meet the PAI content. The activities including various habitual activities that held weekly in order to grow morality and ethical based character.

\section{References}

Gultom, Syawal, Modul Pelatihan Kurikulum 2013, Jakarta: Human Resources Development Agency for Education and Culture and Education Quality Assurance, Ministry of Education and Culture 2014.

------, Standar Operasional Prosedur (SOP) dalam rangka Pelatihan Implementasi Kurikulum 2013, Kemendikbud, Jakarta: Mei 2013.

Hamalik, Oemar, Dasar-dasar Pengembangan
Kurikulum, Bandung: PT. Remaja Rosdakarya, 2007.

Hasan, Evaluasi Kurikulum, Bandung: Remaja Rosdakarya. 2009.

Hidayati, Titiek Rohanah, "Implementasi Pengembangan Kurikulum 2013 Dalam Pembelajaran Pendidikan Agama Islam dan Budi Pekerti Di SMA Negeri 4 Jember", An article in Jurnal Fenomenal (Jember: IAIN Jember, vol. 14, no. 1, April 2015.

Jaedun, Amat V. Lilik Hariyanto, Nuryadin, E.R, "An evaluation of the implementation of Curriculum 2013 at the building construction department of vocational high schoos in Yogyakarta", Journal of Education, vol. 7, no. 1, November 2014.

Jajuli, Mumu, "Kurikulum 2013 Milik Guru PAl”, Pendis. kemenag.go.id, http://www.pendis.kemenag. go.id/pai/index.php?a=detilberita\&id=5640, accessed, March, 32017

Khairiyah, Nelty and Endi Suhendi Zen, Pendidkan Agam Islam dan Budi Pekerti SMA/MA, SMK/ $M A K$, Jakarta, Education and Culture Ministry, 2017.

Kunandar, Guru Profesional Implementasi Kurikulum Tingkat Satuan Pendidikan (KTSP) dan Sukses Dalam Sertifikasi Guru, Jakarta: Raja Grafindo Persada, 2007.

Kuncoro, Hadi, "Peran Kepala Sekolah Dalam Implementasi Kurikulum 2013 di Sekolah Menengah Pertama Negeri 1 Gisting Kabupaten Tanggamus Tahun Pelajaran 2014/2015", Master Thesis, Lampung: Postgraduate Program of Education Management, Faculty of Teaching and Education Sciences, Universitas Lampung, 2015.

Muhaimin, Pengembangan Kurikulum Agama Islam, Jakarta: RajaGrafindo Persada, 2010, Printed. IV.

Mukadi, Djemakin, “Kurikulum 2013: Mata Pelajaran PAl” dalam Gurupaisma1 purbalingga. blogspot. com, published on 10 June 2013, http:// guru paisma 1pur balingga.blogspot.com/ 2013/06/ kurikulum-2013-mapel-pendidikan-agama.html, accessed on March 2, 2014

Moeloeng, Lexy, Metodologi Penelitian Kualitatif, Bandung: Rosdakarya, 1995.

Northcott, Michael S., Sociological Approach, in Apprroaches to the Study Of Religion, Eds: 
Peter Connolly, London, Wellington House, 1999.

Nuh, Muhammad, Paparan Menteri Pendidikan dan Kebudayaan Pengembangan Kurikulum 2013, Semarang: Kemendikbud, June 2013.

Qomaruzzaman, Bambang. "Religious Inclusivityin Islamic Education Course Book of the2013 Curriculum." MADANIA: JURNAL KAJIANKEISLAMAN vol. 22.no. 2, 2018.

Singarimbun, Masri and Sofian Effendi, Metode Penelitian, Jakarta: LP3ES, 1997.

Solikah, Alfiatu, "Pengembangan Tujuan dan Isi Kurikulum Pendidikan Agama Islam”, an article in alfykdr.blogspot.com, published on 16 June 2013, from http://alfykdr.blogspot. com/ 2013/06/tugas-kuliah.html.

Solomon Bediako, "Implementation, Some Definitions and Influence Of Implementation", An article in researchgate.net/publication, accessed on June 6, 2020.

Sulistiyowati, Heny, "Analisis Pelaksanaan Kegiatan Pengembangan Diri Keagamaan dan Life Skill Untuk Meningkatkan Kemandirian Peserta Didik Di SD Muhammadiyah Birrul Walidain Kudus Tahun Pelajaran 2015/2016", Undergraduate Thesis, Kudus, STAIN, 2016. 